\title{
ELDERLY PARENTS, ADULT CHILDREN AND THE ROMANIAN TRANSNATIONAL FAMILY: AN INTERGENERATIONAL SOLIDARITY APPROACH
}

\author{
IONUT, FÖLDES ${ }^{1}$
}

\begin{abstract}
Recent demographic changes such as ageing, low-fertility, and large out-migration from Eastern European countries, brought into discussion the vivid question of the future of intergenerational solidarity within families. In the context of increasing geographical mobility of young people in search for better paid jobs, the unmet need for personal assistance among the elderly, the underdeveloped system of care services, Romania knows new dynamics of intergenerational support. Contrary to perspectives that consider spatial proximity between adult children and their elder parents the indisputable enabling factor for intergenerational support transfers (Rossi and Rossi, 1990), emerging literature on transnational families highlights that such tight kinship relations continue to exist even across borders (Baldassar et al., 2007). Using recent data from the nationwide survey "The Impact of Migration on Older Parents Left Behind in Romania" (2011), this paper examines the complex dynamics of intergenerational solidarity involving adult children as transnational migrants and their elder parents who remain at home. The statistical models used indicate the migrants' role as providers of remittances, but also the ways in which other forms of support are distributed among the dyads. Despite a possible presupposition that parents who were left at home might only be beneficiaries of support, the data show the opposite: elderly persons, depending on their age, were active providers of help as well.
\end{abstract}

Keywords: intergenerational solidarity, transnational families, elderly care, population ageing

\section{Introduction $^{2}$}

This study aims to gain better understanding of how geographic distance between adult-children and their elderly parents influence the provision of intergenerational support within the family. Based on a descriptive approach,

${ }_{1}$ PhD Candidate in Sociology at the Babeș-Bolyai University Cluj-Napoca, e-mail: ionut.foldes@gmail.com.

2 The successful completion of this work would have not been possible without the support received from Professor Zachary Zimmer, University of California and from Codrina Rada, University of Utah, who provided the survey data from "The Impact of Migration on Older Parents Left Behind in Romania". Also, this work was supported by a grant of the Romanian National Authority for Scientific Research and Innovation, CNCS - UEFISCDI, project number PN-II-RU-TE-2014-4-1377. 
it explores several assumptions related to forms of intergenerational support and to the possible providers and beneficiaries of support in different migration contexts.

The contemporary Romanian demographic context of families, briefly discussed below, raises some interesting discussions about the strengths of family ties. It seems that low fertility rate and the increase of life expectancy at older ages influence the reconfiguration of the traditional family model. It can be easily observed that nowadays extended families are composed of more successive generations than they were in the past (Mureșan, 2012a: 231). Moreover, the increase of the generation age gap led to the reduction of family size (Mureșan and Hărăgus, 2015). The increase of the number of successive generations together with the reduction of the number of children for each generation was translated as the verticalization of families (Bengtson et al., 1990).

Migration is another demographic phenomenon which makes our discussion even more salient. Romania is one of the most important countries of out-migration from Eastern Europe to the West (World Bank, 2016). Recent studies about migration emphasize the existence of transnational spaces (social, economic and political spaces) made possible by transmigrants, i.e. social actors defined by their geographic mobility, cross border social relations and networks (Ban, 2012; Basch et al., 2005). Above all, we have witnessed the expansion of transnational families, (Baldassar et al., 2007:14), defined as those extended families whose transmigrant members stay in touch with the non-transmigrant members. International migration is not the only factor influencing the relations between family generations, internal migration holds an effect as well. Consequently, the present paper presents the living arrangements of families and the relationships between parents who remained at home, their adult-children who migrated within the country and those who went abroad.

Before international migration became widespread, Romanians were moving back to rural settlements from de-industrialised cities (Sandu and Alexandru, 2009; Diminescu, 2012). Studies show that internal migration structured remarkably well the patterns of going abroad. Diminescu (2012) revealed the emergence of rural or regional networks of migrants around some representative villages which afterwards have increasingly expanded. Considering these, the paper will provide a comparison in terms of rural-urban differences related to migration status of the adult-children and living arrangements of the multigenerational family.

Moving forward to intergenerational family relations, studies show that there are based on (a) the behaviour that occurs along with the expectation of reward, (b) the result of an altruistic or caring preference and/ or (c) a possible consequence of sharing social norms and values which are culturally built (Bianchi 
et al., 2006; Bawin-Legross and Stassen, 2002). Finch's argument concerning the starting point of support relations relates more to a series of commitments negotiated between family members than to a moral imperative (Baldassar et al., 2007: 15). This paper stands on the concept of intergenerational solidarity (Bengtson and Roberts, 1991) as its central concept. This is a multidimensional concept that describes how cohesion and family integration systems operate (Bengtson and Schrader, 1982; Mangen et al., 1988), such as the issue of "intergenerational cohesion after children reach adulthood and establish careers and families of their own" (Bengtson and Roberts, 1991: 896).

The six dimensions implied, are presented in the following table:

Table 1.

Dimensions of intergenerational solidarity

\begin{tabular}{|l|l|}
\hline Dimensions & Characteristics \\
\hline $\begin{array}{l}\text { Associational } \\
\text { solidarity }\end{array}$ & $\begin{array}{l}\text { Frequency and patterns of interaction in various types of } \\
\text { activities in which family members engage }\end{array}$ \\
\hline Affectual solidarity & $\begin{array}{l}\text { Type and degree of positive sentiments held about family } \\
\text { members, and the degree of reciprocity of these sentiments }\end{array}$ \\
\hline Consensual solidarity & $\begin{array}{l}\text { Degree of agreement on values, attitudes and beliefs among } \\
\text { family members }\end{array}$ \\
\hline Functional solidarity & Degree of helping and exchange of resources \\
\hline Normative solidarity & $\begin{array}{l}\text { Strength of commitment to performance of familial roles and } \\
\text { to meeting familial obligations (familialism) }\end{array}$ \\
\hline Structural solidarity & $\begin{array}{l}\text { Opportunity structure for intergenerational relationships, } \\
\text { reflected in number, type and proximity of family members }\end{array}$ \\
\hline
\end{tabular}

Source: Bengtson and Roberts, 1991: 857.

Therefore, considering the demographic context in Romania and the theoretical model of intergenerational solidarity, this study aims to offer a wider description of transformations related to intergenerational family help transfers. Specifically, using a set of nationally representative micro-data for the elderly population of Romania, it shows how old parents and their adultchildren are involved in transfers of support according to different migration statuses. The stake of the paper is to put together family studies and migration studies in order to explore the influence of geographic distance on the building and maintaining of kin relationships. This represents the main contribution of the study, given that the topic was little explored in Romania so far. 


\section{Transnational family and intergenerational support}

According to Basch et al. (2005), transnationalism is based on four premises as follows: (1) transnational migration is inseparable from what we call global capital and it cannot be studied outside the overall relationship between labour and capital; (2) transnationalism is a process in which migrants create social fields that go beyond national borders; (3) the understanding and study of this phenomenon should be made only by taking into consideration the geographic distance, cultural norms and the degree to which the identity has been assumed; (4) by the fact that migrants are living outside of the borders of their country of origin, they take part in the process of nation building for two or more states.

Transnational families can be defined as a specific type of family whose members live separately for a period of time, but which still keep the desire to contribute to the collective wellbeing and to the family unity even across national borders (Bryceson and Vuorela, 2002: 3). Critics of transnational family say that this form of arrangement is a threat to the good management of nation states and that it is a cause of the rupture of family unity which has bad repercussions on individual's wellbeing. As a reaction to such perspective, anthropology sees family and nation as two parallel structures (Bryceson and Vuorela, 2002: 9). Even more, the authors consider family, ethnicity and nation as "imagined communities", because, despite of the fact that individuals are born in certain families and states, their sense of belonging can be developed or negotiated by each (Bryceson and Vuorela, 2002: 10).

Lately, the literature has enriched the consistency of a series of studies that treated the issue of transnational families. Most of the studies are the result of long period ethnographies which were taken in various geographic areas. These studies show that members of transnational families are involved in the same types of transfers as families whose members are in spatial proximity. Moreover, the support seems to come from both directions and not only from transmigrants (Baldassar et al., 2007; Baldassar, 2007a, 2007b; Wilding, 2006). An explanation for this is given by Litwak and Kulis (1987), stating that the relation between geographical proximity and offering/ receiving support should not be dichotomous, because there are other factors here, such as the complexity of tasks or constraints and limits determined by the existence of national borders.

These research efforts complement the "new" family studies by considering the cases of transnational families (Baldassar et al., 2007). Rossi and Rossi (1990: 422) state that geographic distance reduces the frequency of social interactions, therefore it also reduces by default transfers of support between the members of the intergenerational family. In contradiction, "modified extended family", another 
theoretical approach, sees the family as an agent capable to face the pressures, the effects of modernization (i.e. increasing spatial mobility) (Litwak, 1960). However, time seems to matter. Spending more time abroad diminishes the intensity of parent-child relations of support (Baldassar, 2007a).

The less studied case of Romanian transnational families has high potential due to the complexity of the existing intergenerational relations of support and also the mix of characteristics of developing and developed countries featured by Romania (Zimmer et al., 2014). Here we can mention the cohesive support networks of kinship, firstly based on the sharing the traditional norms related to family obligations and responsibilities, and secondly, based on the existence of a high frequency of co-residence between parents and adultchildren (Nadolu et al., 2007). To these one should add the underdeveloped social protection system, and elderly care services more specifically, that are insufficiently adapted to existing needs and cover only a limited segment of the elderly population (Nadolu et al., 2007).

Even if remittances sent home by transmigrants require certain sacrifices, this decision may result from "negotiated commitments" according to the characteristics of family relations, or a response to social norms of filial obligation towards elderly parents (Baldassar, 2007a). In order to reach the material expectations of those left at home, many migrants live in difficult conditions and are deprived from a range of necessities. These all lead to frustration and sometimes to the decision to discontinue family ties (Schmalzbauer, 2004). For Romania, survey data shows that people perceive the long spatial distance from their families as the main negative consequence of living abroad, but they do not necessary report changes in the quality of family relationships, especially regarding disunion of the family (Toth and Toth, 2006).

It is important to mention that relationship between transmigrants and their parents, as potential beneficiaries of practical support, is not dyadic, but influenced by other factors related to the situation of siblings, such as geographic distance and the strength of the relationship (Zimmer et al., 2014). For Romania, in areas with high incidence of migration, more than one generation cohabit in elderly households. Such living arrangements favour migration, as migrants know that someone from the multigenerational household will be there to take care of frail elderly parents (Pantea, 2011). Moreover, if there are siblings who live in spatial proximity to their parents, they will provide the necessary support, meanwhile using remittances received from those who emigrated (Zimmer et al., 2014). Accordingly, it is assumed that the decision to migrate will be a result of some sort of negotiations between the siblings in order to decide who will take care of their elderly parents and who will go to find better paid jobs and providing financially support. 
One of migrants' most widespread practices towards their families left at home are money transfers. According to the World Bank (2016) Romania was in 2015 the third remittance recipient country in Europe and Central Asia (\$3.2bn). Studies about Romanian migrants in Spain revealed that half of them send money consistently, $35 \%$ monthly, $16 \%$ every $2-3$ months and $28 \%$ occasionally (Toth, 2009). The same report shows that the frequency of remittances increases with the age of adult migrant children. If among young adults the share is $72 \%$, for those aged over 40 years the percentage increases to 91\% (Toth, 2009). Also, the author states that the frequency increases for transnational households (95\%), especially when children are left at home (99\%) as compared to situations when all family members have emigrated (85\%) (Toth, 2009). A number of differences can be observed regarding the time spent in the destination country. As time passes, the amount of money sent home seems to go on a descending line, possibly as a result of various factors such as the relocation of entire households in the country of destination (Toth, 2009).

The remittances sent by Romanian migrants in Spain are used primarily for daily expenses, so that it represents a necessary money supplement in order to cover household expenses (Toth, 2009). Other expenses were the "products for healthcare, personal and work home improvement" and to a lesser extent "durables expenses, children's education, payment of debts or loans, purchase of housing or land" (Toth, 2009). Other expenditures concern healthcare products, personal goods, and house renovation and to a smaller degree durable goods, children's education, payment of debts or loans, purchase of housing or land (Toth, 2009).

Thus, the importance of financial aid offered by adult children who work abroad is considerable. However, this urges to question how international migrant adult-children relate to other forms of intergenerational support and which are the differences between internal and external migrants in terms of the types of support provided. Practical help, for instance, cannot to be totally neglected. In the case of internal migrated adult-children, a balance between material and practical help can be assumed.

\section{The situation of elderly persons left at home}

A first aspect to be mentioned when dealing with elderly issues in various situations such as that of transnationalism is that this category of the population includes several generations: older adults (55-65 years), relatively younger elderly ( 65-79 years) and relatively older (80 and over) (Baldassar, 2007a; Mureșan, 2012a). 
Research has shown that norms of obligation toward family members have a predictive value for the actual exchange of care. This form of support is perceived in Southern and Central European countries as a responsibility of the family, meanwhile in Northern Europe this is not the case (Haberkern and Szyldik, 2010). Moreover, intergenerational care is more prevalent in the first two European regions, where the legislation coerce the family to provide support to the parents in need (Haberkern and Szydlik, 2010), or where the state evade from its responsibilities of social protection (Isengard and Szydlik, 2012).

Considering these age groups, the degree of involvement and types of transfers between the elderly and their adult-children will vary significantly. Through the influence of age, caring transfers will be provided both upwards and downwards on the generational line. In the case of transnational families, most often elderly will give this kind of support to the younger generation in the early stages of migration, but over time the situation is reversed due to the increasing age and needs of the parents (Baldassar, 2007a).

Regarding gender, when women move abroad for paid labour, their responsibilities from home are taken over by other women, usually by (not very old) grandmothers or other female relatives (Schmalzbauer, 2004). The presence of a partner is another important factor, old widow parents have more chances to receive support from their adult-children. Unfavourable health condition increases the risk of needing support so we expect that it should also increase the probability of intergenerational transfers. Zimmer et al. (2014) shows that along with the increasing of vulnerability of the beneficiary of support, geographic distance becomes less and less important.

When grandparents (usually grandmothers) take into care their grandchildren, some various types of living arrangements have to be considered. Not always the dyads live in the same household. When this happens, grandparents change their residence for a limited period of time in order to be closer to the beneficiaries of support, or if the distance is insignificant, they will shift periodically and for a short time from their home to the place where their grandchildren live (Pantea, 2011). Change of residence abroad, even shortly, causes psychological distress due to the inability to adapt to a totally new environment (Pantea, 2011). In the opposite situation, when grandchildren move into their grandparents' home, the reaction of the elderly, under these circumstances, may range from the creation of an environment fully adapted to the lifestyle of children to a social life strictly subordinated to domestic tasks related to childcare (Pantea, 2011).

Correspondingly, the last assumption that guides this explanatory study concerns reciprocity in the exchange relations. Intergenerational transfers of help are not unidirectional, both adult children and elderly parents provide support to each other. 
IONUȚ FÖLDES

\section{Methodology}

This work is based on data from "The Impact of Migration on Older Parents Left Behind in Romania" (IPIA) survey undertaken in 2011. Data was collected by the Centre for Urban and Regional Sociology (CURS) with financial support from the Centre on Ageing, University of Utah (CURS, 2011). The questionnaire follows several topics, such as living arrangements of the elderly, the situation of their household, intergenerational transfers of help, associational solidarity and socio-demographic characteristics. The survey was conducted in 2011 among 1,125 elderly parents aged 60 and above, plus a boost sample of 384 respondents aged 60 and above with migrant adult-children (CURS, 2011).

After computing new variables and composite indexes tested with Cronbach's alpha ${ }^{3}$, in the first step of the analysis I used descriptive statistics to assess the differences between diverse living arrangements by migration status. The second step relied on multiple correspondence analyses ${ }^{4}$ for intergenerational help given and received by parents to/ from adult-children.

For the receiving of support from adult-children a new variable was computed with four categories, as follows: (1) material support (money and goods), (2) instrumental or time consuming support (care, household duties), (3) both material support and instrumental support, (4) no help received. For providing support, two different variables were used, one identical with the above mentioned, and the other reflecting child care support, measured on an ordinal scale: (1) no support given, (2) seasonal, (3) occasional and (4) frequent. In order to have a clear image, two control variables were used, one referring to the period passed since the adult-child went abroad and the second to associational solidarity, which was measured by the frequency of conversations between dyads using mobile phones or the Internet.

\section{Descriptive results}

Table 2 presents descriptive statistics for different types of migration in rural and urban Romania. From the total population, approximately $38 \%$ of elderly parents live in the same household with their adult-children. Half of the parents (50\%) have internal migrated adult-children, $28 \%$ of them moved

3 The Cronbach's alpha test is the most wildly used in order to show internal consistency. Varying from 0 to 1 , the more similar the items, the higher alpha is likely to be.

4 Correspondence analysis tests the association between variables and gives numerical values to those measured on a nominal scale (Culic, 2004: 215). Each case is represented on a dimensional plan in proximity with the other cases from the same category, meanwhile cases from different categories are positioned as distant as possible one from each other (Culic, 2004). 
in another locality and 22\% changed their residence in others counties. Less high, but significant, is the percent of parents who have children across national borders (13\%). Visible discrepancy between rural and urban settlements can be observed for internal migration in the same county and for the case of nomigration. There are more parents in rural areas whose adult-children moved most probably in the closest city or in the county administrative centre. The highest percentage of parents with adult-children who live in the same locality is found for urban settlements. This can be a hint for saying that adult-children are in search for better jobs, and the cities, obviously, offer more opportunities for employment. Also, these can result from enrolment in higher education of young adults from rural areas, at times followed by the decision to prolong their stay in the city. Considering outmigration, discrepancies between rural and urban are much smaller comparative with the other two situations mentioned above.

Table 2.

Descriptive results for migration status of adult-children by type of settlement in Romania in 2011

\begin{tabular}{|c|c|c|c|c|}
\hline & \multicolumn{2}{|c|}{ Type of settlement } & \multirow{2}{*}{ Total } \\
\hline & & Urban & Rural & \\
\hline \multirow[t]{2}{*}{ Same locality (non-migrants) } & Frequency & 334 & 177 & 511 \\
\hline & Percentage & $52 \%$ & $25 \%$ & $37.52 \%$ \\
\hline \multirow{2}{*}{$\begin{array}{l}\text { Other locality in the same county } \\
\text { (internal migrants) }\end{array}$} & Frequency & 90 & 284 & 374 \\
\hline & Percentage & $14 \%$ & $39 \%$ & $27.46 \%$ \\
\hline \multirow{2}{*}{$\begin{array}{l}\text { Other county/ The Capital } \\
\text { (internal migrants) }\end{array}$} & Frequency & 139 & 161 & 300 \\
\hline & Percentage & $22 \%$ & $22 \%$ & $22.03 \%$ \\
\hline \multirow{2}{*}{$\begin{array}{l}\text { Other country (international } \\
\text { migrants) }\end{array}$} & Frequency & 78 & 99 & 177 \\
\hline & Percentage & $12 \%$ & $14 \%$ & $13.00 \%$ \\
\hline \multirow[t]{2}{*}{ Total } & Frequency & 641 & 721 & 1,362 \\
\hline & Percentage & $100 \%$ & $100 \%$ & $100 \%$ \\
\hline
\end{tabular}

Data source: IPIA, 2011. Author's calculations.

Regarding adult-children living in the same household with their parents (Table 3), 88\% have never left the parental household by the time of data collection and $12 \%$ have left, but returned. The rate of temporary internal migration followed by return home is higher in rural areas. This may be a result of failure in finding a better job. Consequently, our overall picture indicates that adults living with their parents are not as mobile as those living independently or with their families. 
Table 3.

Descriptive results for spatial mobility of adult-children who live with parents

\begin{tabular}{|c|c|c|c|c|c|}
\hline & \multicolumn{2}{|c|}{ Type of settlement } & \multirow[t]{2}{*}{ Total } \\
\hline & & & Urban & Rural & \\
\hline \multirow{4}{*}{$\begin{array}{l}\text { Adult-child lived for } \\
\text { at least } 6 \text { months in } \\
\text { other locality? }\end{array}$} & \multirow[t]{2}{*}{ Yes } & Frequency & 40 & 67 & 107 \\
\hline & & Percentage & $8 \%$ & $16 \%$ & $12 \%$ \\
\hline & \multirow[t]{2}{*}{ No } & Frequency & 431 & 352 & 783 \\
\hline & & Percentage & $92 \%$ & $84 \%$ & $88 \%$ \\
\hline \multirow{2}{*}{\multicolumn{2}{|c|}{ Total }} & Frequency & 471 & 471 & 419 \\
\hline & & Percentage & $100 \%$ & $100 \%$ & $100 \%$ \\
\hline
\end{tabular}

Data source: IPIA, 2011. Author's calculations.

Table 4 comparatively presents the status of migrants for the first four possible adult-children. We see a number of categories that highlight the presence or absence of adult-children in the parent's household. As we observed in Table 2, 38\% of parents have all their adult-children spatially immobile, which is also the modal category. On second place, all adult-children are internal migrants $(27 \%)$. In the third situation, adult children can be internal migrants and non-migrants as well (22\%). An interesting observation is that the highest percentage of international migration is for cases when all adult-children are living abroad. There are very few cases when adult-children have all three different statuses $(2.5 \%)$. Comparing areas of residence, rural localities register higher migration than urban places.

Table 4.

Descriptive results for migration status comparative for the first four adult-children by type of settlement

\begin{tabular}{|c|c|c|c|c|}
\hline & \multicolumn{2}{|c|}{ Type of settlement } & \multirow[t]{2}{*}{ Total } \\
\hline & & Urban & Rural & \\
\hline \multirow[t]{2}{*}{ All international migrants } & Frequency & 33 & 29 & 62 \\
\hline & Percentage & $5.2 \%$ & $4.0 \%$ & $4.6 \%$ \\
\hline \multirow[t]{2}{*}{ All internal migrants } & Frequency & 123 & 244 & 367 \\
\hline & Percentage & $19.3 \%$ & $33.8 \%$ & $27.0 \%$ \\
\hline \multirow[t]{2}{*}{ All non-migrants } & Frequency & 334 & 181 & 515 \\
\hline & Percentage & $52.3 \%$ & $25.1 \%$ & $37.8 \%$ \\
\hline \multirow{2}{*}{$\begin{array}{l}\text { At least: one international migrant, one } \\
\text { internal migrant and one non-migrant }\end{array}$} & Frequency & 8 & 26 & 34 \\
\hline & Percentage & $1.3 \%$ & $3.6 \%$ & $2.5 \%$ \\
\hline \multirow{2}{*}{$\begin{array}{l}\text { All international migrants and internal } \\
\text { migrants, no non-migrants }\end{array}$} & Frequency & 12 & 26 & 38 \\
\hline & Percentage & $1.9 \%$ & $3.6 \%$ & $2.8 \%$ \\
\hline
\end{tabular}




\begin{tabular}{|l|l|l|l|l|}
\hline \multicolumn{2}{|c|}{} & \multicolumn{2}{l|}{ Type of settlement } & Total \\
\cline { 3 - 5 } \multicolumn{2}{|c|}{} & Urban & Rural & \\
\hline \multirow{2}{*}{$\begin{array}{l}\text { All international migrants and non- } \\
\text { migrants, no internal migrants }\end{array}$} & Frequency & 25 & 20 & 45 \\
\cline { 2 - 5 } $\begin{array}{l}\text { All internal and non-migrants, no } \\
\text { external migrants }\end{array}$ & Percentage & $3.9 \%$ & $2.8 \%$ & $3.1 \%$ \\
\hline \multirow{2}{*}{ Total } & Frequency & 104 & 196 & 300 \\
\cline { 2 - 5 } & Percentage & $16.3 \%$ & $27.2 \%$ & $22.0 \%$ \\
\cline { 2 - 4 } & Frequency & 639 & 722 & 1,361 \\
\cline { 2 - 4 } & Percentage & $100 \%$ & $100 \%$ & $100 \%$ \\
\hline
\end{tabular}

Data source: IPIA, 2011. Author's calculations.

Similar with the previous one, Table 5 presents the relation between the migration status of the oldest adult-child and spatial mobility of the siblings. If the first born child engages in international migration, then in $24 \%$ of the cases his/her siblings are also living across borders. This trend seems to repeat when the oldest adult-child engages in internal migration, as $34 \%$ of his/her siblings are internal migrants too. Conversely, almost half of non-migrants older adult-children (41\%) have their siblings living in the same locality with them and with their parents. This should be a result of migration based on kin and family networks (Anghel, 2008). If the siblings did not leave the country together, probably the oldest adult child managed, after a period of time, to create work opportunities for his or her siblings and brought them with him or her. Regarding their parents, it is highly probable that they have no necessities in terms of personal assistance, or, if it is the case, another relative will handle the responsibility (probably the spouse or partner).

Table 5.

Descriptive result for the comparison between the migration status of the oldest adult-child and the migration status of his or her siblings

\begin{tabular}{|c|c|c|c|c|c|c|}
\hline & \multicolumn{3}{|c|}{ The oldest adult-children } & \multirow[t]{2}{*}{ Total } \\
\hline & & & $\begin{array}{l}\text { External } \\
\text { migrant }\end{array}$ & $\begin{array}{l}\text { Internal } \\
\text { migrant }\end{array}$ & $\begin{array}{l}\text { Non- } \\
\text { migrant }\end{array}$ & \\
\hline \multirow[t]{8}{*}{ Siblings } & \multirow{2}{*}{$\begin{array}{l}\text { All international } \\
\text { migrants }\end{array}$} & Frequency & 25 & 19 & 20 & 64 \\
\hline & & Percentage & $24.3 \%$ & $3.4 \%$ & $2.9 \%$ & $4.7 \%$ \\
\hline & \multirow{2}{*}{$\begin{array}{l}\text { All internal } \\
\text { migrants }\end{array}$} & Frequency & 11 & 192 & 105 & 308 \\
\hline & & Percentage & $10.7 \%$ & $34.1 \%$ & $15.1 \%$ & $22.6 \%$ \\
\hline & \multirow[t]{2}{*}{ All non-migrants } & Frequency & 14 & 105 & 283 & 402 \\
\hline & & Percentage & $13.5 \%$ & $18.7 \%$ & $40.7 \%$ & $29.5 \%$ \\
\hline & \multirow{2}{*}{$\begin{array}{l}\text { External migrant, } \\
\text { internal migrant } \\
\text { and non-migrant }\end{array}$} & Frequency & 2 & 2 & 2 & 6 \\
\hline & & Percentage & $1.9 \%$ & $0.4 \%$ & $0.3 \%$ & $0.4 \%$ \\
\hline
\end{tabular}




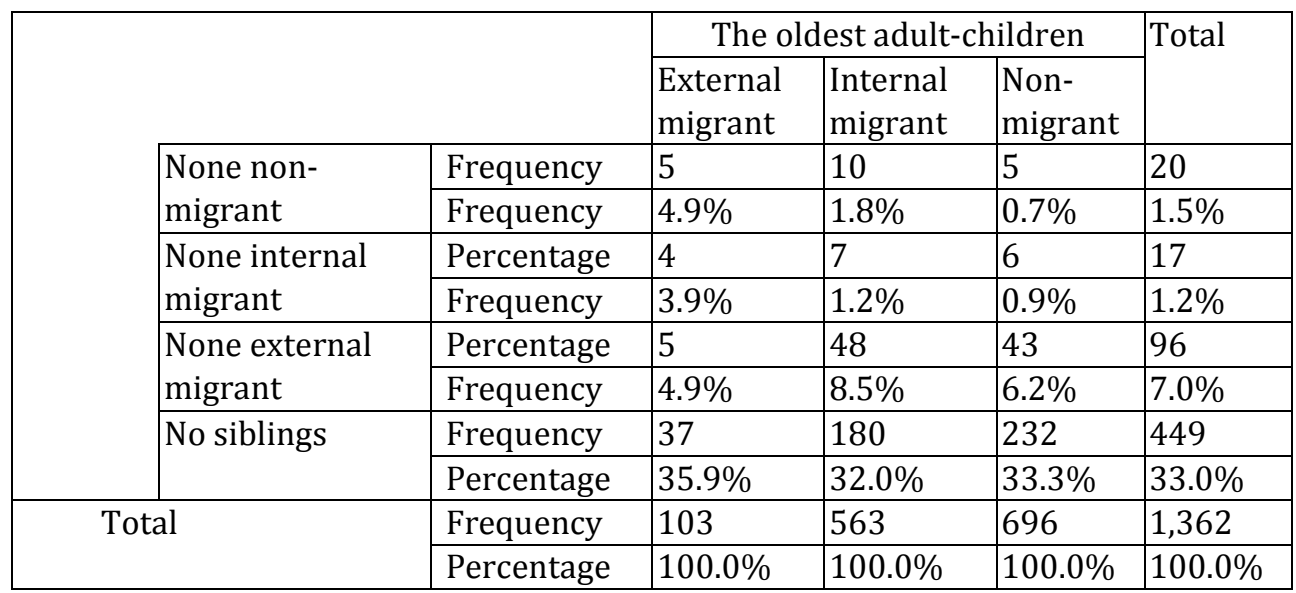

Data source: IPIA, 2011. Author's calculations.

\section{Spatial mobility and intergenerational support}

The following tables and figures reproduce multiple correspondence analysis results for intergenerational support from both directions. In order to produce these analyses, new variables were built for the two categories of actors involved in transfers of support (adult-children and parents), which include forms of support mentioned before.

For the best possible data accuracy, I examined the relationship between parents and their oldest adult-child. Correspondingly, for the variable describing the situation of benefiting from the support of adult-children, I used four categories, as follows: (1) material support, (2) instrumental, (3) both, and (4) no type of support. For receiving material support, the following items were employed: "During the past year, has your oldest child given you or your spouse any money?", "During the past year, has your oldest child helped you with food or other goods?", "Has your oldest child ever contributed with a substantial amount of money for improving your house or building a new house?", "Has your oldest child ever bought or given to you a major household item (car, appliance, etc)?".

Instrumental support was measured using the following questions: "During the past year, has your oldest child helped you with housework (cooking, cleaning)?" and "During the past year, has your oldest helped you with your work, business or farm?".

For parents two variables were built, one computed with the categories mentioned above and a second one, specifically referring to care for the grandchildren. This variable has a number of categories based on how often 
support is provided (do not offer at all, only seasonally, occasionally or frequently). The questions used for providing material support were as follows: "During the past year, have you or your spouse given assets or financial help (loans) to your oldest child?" and "During the past year, have you or your spouse given food or other items to your oldest child?". For measuring the provision of practical support two items were employed: "During the past year, have you or your spouse helped your oldest child with housework other than childcare?" and "During the past year, have you or your spouse helped your oldest child with work, business or on the family farm?". The last type of practical help is caring for grandchildren: "During the past year, have you or your spouse helped your oldest child with childcare?". When the answer was "Yes, during school vacations", support was considered to be provided seasonally. If help was provided several times or monthly, the "occasionally" category was used, while for help offered almost daily or weekly the "frequently" category was assigned.

Types of support, both given and received, have been treated differently in situations where adult-children are external migrants as compared to internal migrants. This was measured by asking the respondent "Where does your oldest child live?". Internal migration was considered when the answer was the same county, but a different locality within or outside of the county, International migration was considered when the parent declared that his or her oldest child was living abroad.

As an attempt to bring new information and to control the time effect and frequency of contact, new multiple correspondence models were created. The time effect was controlled with the help of a variable measuring the time elapsed from the moment of leaving the parental home. The questions were formulated as follows: "How long ago did your oldest child move away from your household?". The minimum period is one year, and the last grouping interval of the scale is more than 25 years. The second variable measures how much parents and adult-children discuss with each other on the telephone or via the Internet. The variable was computed by taking into consideration the migration status of the oldest adult child and the frequency of discussions (using telephone, email, SMS) from the past 12 months.

In the total sample of 1,509 respondents aged 60 or above, 516 persons have international migrant children, 885 persons have no children abroad and 108 have no children at all. For the analyses data were weighted, therefore the absolute frequencies for all three categories have been changed. There were 103 cases where the oldest adult child is an international migrant. Irrelevant cases (no migrant children or no children at all) were excluded from the analysis (recoded into missing values). 


\section{Transnational families}

Tables 6.1 to 6.4 and Figure 1 present information from multiple correspondence analysis, the Cronbach's Alpha test, relative frequency distribution, contribution of variable categories to the two dimensions and the graphic results of the analysis (joint plot of category points) of the variables that describe the intergenerational support between parents left at home and international migrant adult-children.

Relative frequency distribution and contribution of

Table 6.1. variable categories to the two dimensions for benefiting help from the international migrant adult-child

\begin{tabular}{|l|l|l|l|}
\hline Category & Relative & \multicolumn{2}{|l|}{ Centroid Coordinates } \\
\cline { 3 - 4 } & \multirow{2}{*}{$\begin{array}{l}\text { Frequency } \\
\text { (\%) }\end{array}$} & Dimension \\
\cline { 3 - 4 } & $96.6 \%$ & .815 & .219 \\
\hline Material & $1.1 \%$ & -3.695 & 2.470 \\
\hline Instrumental & $1.5 \%$ & -4.006 & 3.776 \\
\hline Both & $0.8 \%$ & -2.804 & -2.647 \\
\hline No help &
\end{tabular}

Data source: IPIA, 2011. Author's calculations.

Table 6.2.

Relative frequency distribution and contribution of variable categories to the two dimensions for providing help to the international migrant adult-child

\begin{tabular}{|l|l|l|l|}
\hline \multirow{2}{*}{ Category } & \multirow{2}{*}{$\begin{array}{l}\text { Relative } \\
\text { Frequency }\end{array}$} & \multicolumn{2}{|c|}{ Centroid Coordinates } \\
\cline { 3 - 4 } & $(\%)$ & Dimension \\
\cline { 3 - 4 } & $15.8 \%$ & 1 & 2 \\
\hline Material & $5.4 \%$ & -2.451 & 1.405 \\
\hline Instrumental & $6.7 \%$ & -3.995 & 2.644 \\
\hline Both & $72.1 \%$ & -1.477 & 4.527 \\
\hline No help & & -1.974 \\
\hline
\end{tabular}

Data source: IPIA, 2011. Author's calculations.

As the frequencies from Table 6.1 show, the most frequent type of help received from adult-children living abroad is material. Table 6.2 and Table 6.3 show poor involvement of parents in providing intergenerational support. This can be seen as a sign of deprivation among the elderly people left at home. Poor 
health condition and low income makes provision of help to their sons and daughters left abroad almost impossible. On the contrary, in the majority of cases in order to meet their needs, help from children living abroad is requested. When parents have the possibilities to offer support to their adult-children living in another country, the most frequent are material aid and seasonal childcare. Typically during the first critical period of finding work and accommodation abroad, material support from parents can be crucial. Also, when grandchildren are in school vacations, grandparents seem to be the suitable option for childcare.

Table 6.3.

Relative frequency distribution and contribution of variable categories to the two dimensions for providing childcare to the international migrant adult-child

\begin{tabular}{|c|c|c|c|}
\hline \multirow[t]{3}{*}{ Category } & \multirow{3}{*}{$\begin{array}{l}\text { Relative } \\
\text { Frequency } \\
(\%)\end{array}$} & \multicolumn{2}{|c|}{ Centroid Coordinates } \\
\hline & & \multicolumn{2}{|c|}{ Dimension } \\
\hline & & 1 & 2 \\
\hline Seasonal & $14.5 \%$ & -2.569 & 1.245 \\
\hline Occasional & $2.5 \%$ & -3.207 & 3.744 \\
\hline Frequent & $10.0 \%$ & -2.992 & 2.603 \\
\hline No help & $73.0 \%$ & -1.603 & -1.825 \\
\hline
\end{tabular}

Data source: IPIA, 2011. Author's calculations.

Table 6.4.

Summary of multiple correspondence model for intergenerational transfers with international migrant adult-child

\begin{tabular}{|l|l|l|l|}
\hline \multirow{2}{*}{ Dimension } & \multirow{2}{*}{$\begin{array}{l}\text { Cronbach's } \\
\text { Alpha }\end{array}$} & \multicolumn{2}{|l|}{ Variance Accounted For } \\
\cline { 3 - 4 } & .861 & Total (Eigenvalue) & Inertia \\
\hline 1 & .672 & 2.346 & .782 \\
\hline 2 & & 1.811 & .604 \\
\hline Total & 4.157 & 1.386 \\
\hline Mean & $.778^{\mathrm{a}}$ & 2.079 & .693 \\
\hline
\end{tabular}

Data source: IPIA, 2011. Author's calculations.

Looking at Figure 1, it can be observed how the categories of help were grouped in a two-dimensional plan. One group consists of elderly parents who receive both types of support (material and time consuming) and also who offer material, practical and, occasionally, childcare for their grandchildren. The second group represents the cases when parents offer and receive instrumental help and 
childcare is frequently provided. In the third group, this time, parents are only providers of support (material and seasonal childcare). The last group show no intergenerational help transfers. Considering the two dimensions of the analysis, it can be observed that the first one discriminates only the situation when adult-children offer material support. In other words, the primary role of the adult-child who migrates abroad for work to provide remittances is highlighted. The second dimension groups the categories in such a way that short-term reciprocal relationships stand out (Leopold and Raab, 2011). Considering that practical help involves physical contact, while material support does not, we can say that, as expected, face to face meetings are not frequent between dyads. However, when the family reunites, even for short periods of time, both members of the two generations contribute with different types of help.

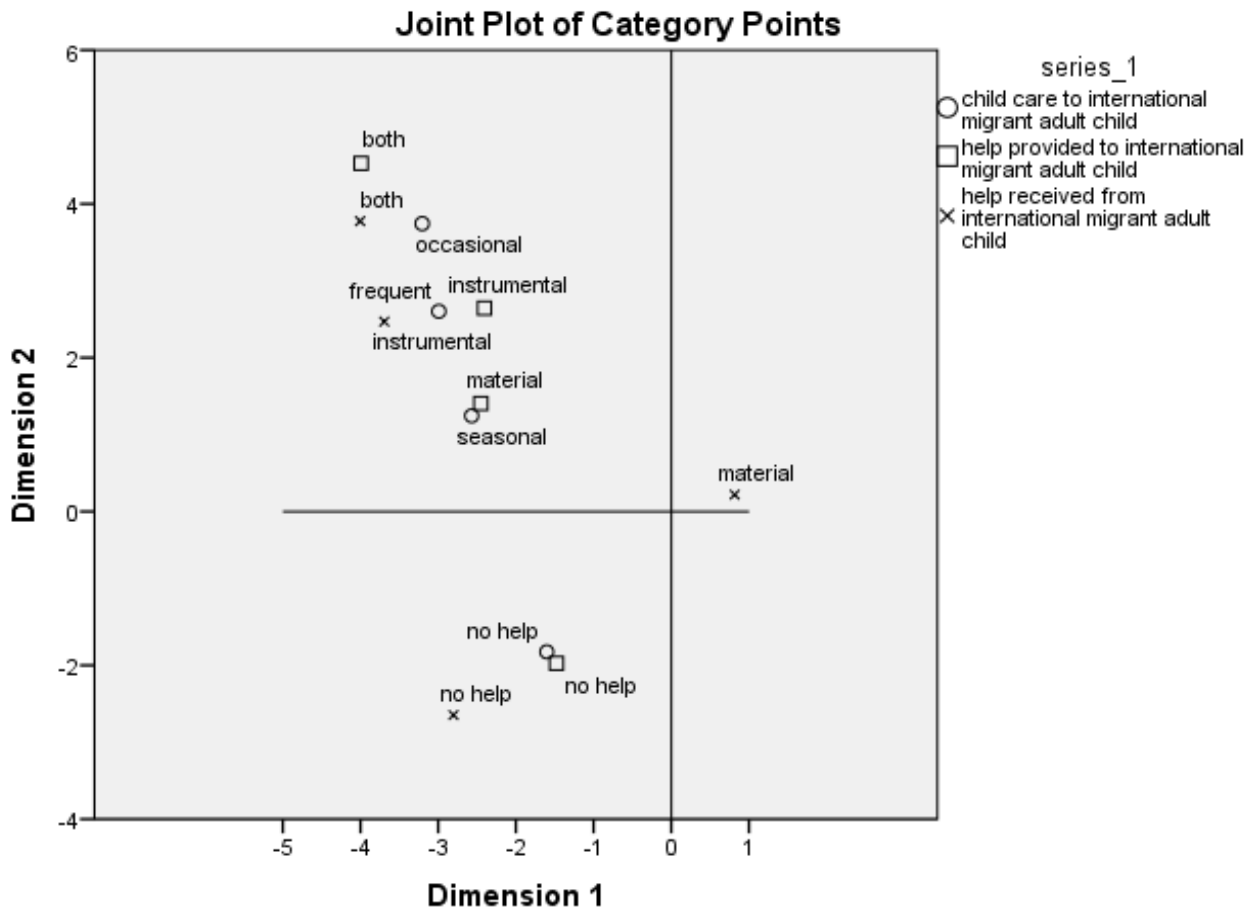

Variable Principal Normalization.

Figure 1. Plot of category points for multiple correspondence model for intergenerational transfers with international migrant adult-child

Data source: IPIA, 2011. Author's calculations. 
Controlling for the effect of time spent abroad among international adult-child migrants and the frequency of contact by telephone or the Internet between adult-children left abroad and their parents in Romania, the multiple correspondence models show, at first sight, intuitive information about the effect of the two new analyzed variables (see Table A1 and Figure A1 from Appendix A). Regarding our time-related variable, the bi-dimensional plot showed that the only category explained by the first dimension is material help provided by adult children who work abroad. The second dimension captures the type and intensity of all other forms of support and also a maximum period of 14 years since the adult child went to work abroad for the first time. Here, groups cannot be clearly identified according to forms of support and the time related variable. However, the categories describing the lack of any transfers seem to be closely related to the very long period spent abroad by adult-children (20-24 years and 25 years and above). This can be a clue of rupture of family ties after a long period of separation. Another possible explanation is related to the characteristics of different migration regimes in Romania (see Horvath, 2012: 199). International migrants who had left the country for more than 20 years have specific mobility patterns, socio-demographic characteristics and family backgrounds, different from later migrant cohorts.

These results reinforce the statement regarding the main role of the transnational migrants. For a relatively long period of time, adult-children contribute financially to the wellbeing of their parents. Other forms of support, provided or received by elderly parents, are more time-dependent than material support. Having children living for more than two decades in another country, intergenerational transfers of support might no longer be present. Because correspondence analysis does not imply causality, the relation between time and transfers is seen as indirect, so that possibly other factors offer better explanation for the change in the support provided. Such factors could be health related problems among the elderly that occur along with ageing, grandchildren no longer requiring childcare, or the fact that adult children established careers and families abroad, turning their full attention to their "new" lives.

The second variable was used to control the relationships of support between generations living apart by the frequency of technology mediated contact (see Table A2 and Figure A2 from Appendix A). As it was the case in previous analyses, the first dimension discriminates only for material help received from adult-children. Very often discussions seem to be in the same group with provision of material support and seasonal childcare by parents. Since the other categories are grouped together, no or rare discussions might be a sign of a weak kinship bonds and consequently an indicator of the lack of intergenerational support. As it was mentioned before, intergenerational solidarity is constructed on multiple pillars. Frequency of help (functional solidarity) and frequency of contact (associational solidarity) in this case are positively related. 


\section{Family relations inside the national frontiers}

This section presents the results of three multiple correspondence models concerning intergenerational transfers between members of extended families, who are resident in different localities, but in the same country. Regarding the frequency of intergenerational support beneficiated and received, Tables 7.1, 7.2 and 7.3 show the weighted frequency for each category. The highest share of support from adult-children to elderly parents regards care and household duties, which are both time consuming. Compared to parents who receive intergenerational support, it can be observed that very few do not benefit from any kind of help from their internal migrant adult-children. The most common intergenerational downward support is material and childcare offered only once a month or less. As in the previous set of analyses, one can see high frequency of parents who do not offer any form of support to their internal migrant adult-children.

Table 7.1.

Relative frequency distribution and contribution of variable categories to the two dimensions for benefiting help from the internal migrant adult-child

\begin{tabular}{|l|l|l|l|}
\hline \multirow{2}{*}{ Category } & Relative & \multicolumn{2}{|l|}{ Centroid Coordinates } \\
\cline { 3 - 4 } & \multirow{2}{*}{$\begin{array}{l}\text { Frequency } \\
(\%)\end{array}$} & \multicolumn{2}{|c|}{ Dimension } \\
\cline { 3 - 4 } & $23.6 \%$ & -.833 & -.473 \\
\hline Material & $49.8 \%$ & .456 & .593 \\
\hline Instrumental & $21.5 \%$ & .289 & -.257 \\
\hline Both & $5.0 \%$ & -.448 & -.082 \\
\hline No help &
\end{tabular}

Data source: IPIA, 2011. Author's calculations.

Table 7.2.

Relative frequency distribution and contribution of variable categories to the two dimensions for providing help to the internal migrant adult-child

\begin{tabular}{|l|l|l|l|}
\hline \multirow{2}{*}{ Category } & \multirow{2}{*}{$\begin{array}{l}\text { Relative } \\
\text { Frequency }\end{array}$} & \multicolumn{2}{|c|}{ Centroid Coordinates } \\
\cline { 3 - 4 } & $(\%)$ & Dimension \\
\cline { 3 - 4 } & $46.0 \%$ & .080 & 2 \\
\hline Material & $2.4 \%$ & .720 & -304 \\
\hline Instrumental & $13.7 \%$ & 1.950 & -.542 \\
\hline Both & $37.9 \%$ & -.893 & -.619 \\
\hline No help &
\end{tabular}

Data source: IPIA, 2011. Author's calculations. 
Table 7.3.

\begin{abstract}
Relative frequency distribution and contribution of variable categories to the two dimensions for providing childcare to the internal migrant adult-child
\end{abstract}

\begin{tabular}{|l|l|l|l|}
\hline \multirow{2}{*}{ Category } & \multirow{2}{*}{$\begin{array}{l}\text { Relative } \\
\text { Frequency }\end{array}$} & \multicolumn{2}{|l|}{ Centroid Coordinates } \\
\cline { 3 - 4 } & $(\%)$ & Dimension \\
\cline { 3 - 4 } & $14.3 \%$ & .699 & 2 \\
\hline Seasonal & $5.0 \%$ & 2.445 & 1.028 \\
\hline Occasional & $7.3 \%$ & 1.370 & -1.134 \\
\hline Frequent & $73.4 \%$ & -.493 & -.026 \\
\hline No help &
\end{tabular}

Data source: IPIA, 2011. Author's calculations.

Table 7.4.

\title{
Summary of multiple correspondence model for intergenerational transfers with internal migrant adult-child
}

\begin{tabular}{|l|l|l|l|}
\hline \multirow{2}{*}{ Dimension } & Cronbach's & \multicolumn{2}{|c|}{ Variance Accounted For } \\
\cline { 3 - 4 } & Alpha & Total (Eigenvalue) & Inertia \\
\hline 1 & .591 & 1.651 & .550 \\
\hline 2 & .466 & 1.451 & .484 \\
\hline Total & & 3.102 & 1.034 \\
\hline Mean & $.533^{\mathrm{a}}$ & 1.551 & .517 \\
\hline
\end{tabular}

Data source: IPIA, 2011. Author's calculations.

This time, the first dimension does not discriminate only one category of help. It can be observed that both parents and adult-children have key roles. First group constituted in the two-dimensional plot shows close relation between material support from parents, seasonal childcare and practical help received from adult children. Looking at the second dimension, the proximity of "no help" categories can be spotted. The case of parents who do not take care of their grandchildren is in the vicinity of the case when no support is received from adult children. Also, another group can be observed, formed by two categories: material aid offered by adult children and neither material nor instrumental help provided to adult children. The first group corresponds with a pattern often discussed in the literature, showing that parents offer lifelong material support to their children while they receive instrumental support in situations of needs from their adult-children (Leopold and Raab, 2011; Mureșan, 2012a and 2012c; Földes, 2015). Due to the geographic distance, childcare is possible only seasonally, when grandchildren are in school vacations and working 
parents have to require help from grandparents. Material support from the youngest generation members is not related with offering material or instrumental help to adult-children. This may be a hint for the poor economic situation and health condition of parents. Parents are not able to travel long distances in order to visit their adult children and help them with household duties and their limited income increases the need for financial aid from other family members.

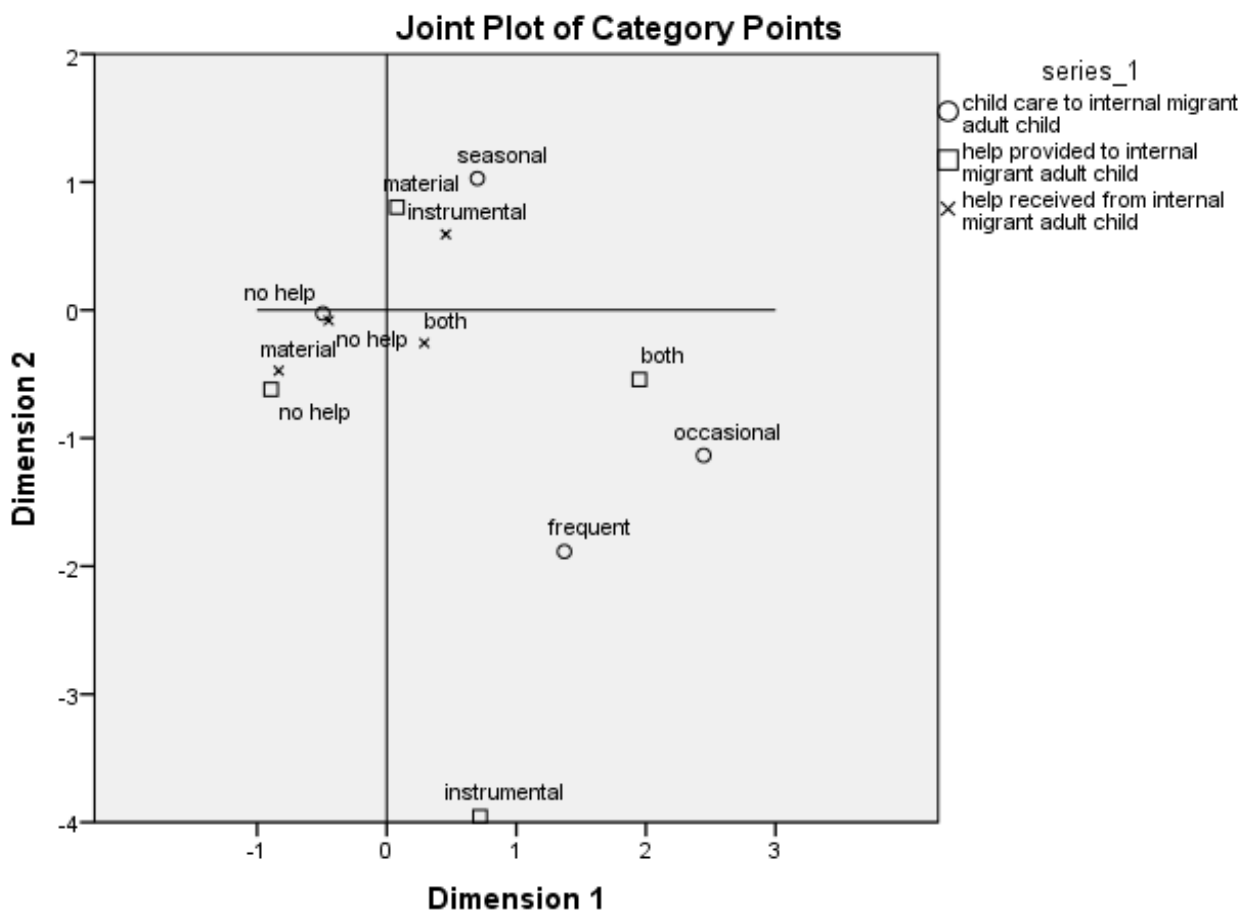

Variable Principal Normalization.

Figure 2. Plot of category points for multiple correspondence model for intergenerational transfers with internal migrant adult-child

Data source: IPIA, 2011. Author's calculations.

As in the previous case, two different multiple correspondence models were created which include time related variables and frequency of contact by telephone or the Internet between dyads (see Appendix B). The first joint plot of category points shows that the first dimension brings ahead a group consisted of the following categories: material help received from internal 
migrant adult-children, no childcare provided and 25 years and above passed since adult-children left the parental home and moved in different locality. Close to this points is positioned the case when neither material, nor practical help is provided to internal migrant adult-children. Postulating that our timerelated variable goes along with ageing, the result supports the interpretation previously provided. Parents' poor living conditions do not allow them to offer any kind of support to their adult children and the needy life requires help from the youngest. Due to the distance and the busy life of adult children, the most convenient type of support is material.

For the frequency of contact mediated by technology, only one category is positioned close to a category describing transfers of help. It is observed that parents receive material and time consuming help (or practical help) if they also discuss often via the phone or the Internet. In addition, the first dimension also surprises the provision of all three types of support to internal migrant adult-children. Another group is formed by frequent discussions, instrumental help received, material and seasonal childcare provided. The second dimension groups the situations when communication occurs rarely and when transfers are just material and ascending. Therefore, it seems that the frequency of indirect contact is related to actual help. Once again, the existence of links between intergenerational solidarity dimensions is evident. Associational solidarity and functional solidarity are positively connected: when the contact is frequent, the provision of help is more visible.

\section{Discussions}

The Romanian demographic context, characterized by below replacement fertility rates and massive international migration, produces transformations of family relations, especially regarding intergenerational relations between members of extended families. The rising number of elderly population and youth migration for work abroad raises more and more questions about the ways in which families could ensure welfare for their members, and also about how migration influences the intergenerational transfers of support. Using statistical analyses on the IPIA 2011 dataset, this paper tried to capture an overall picture of this phenomenon. As most of the studies in the field embraced so far qualitative approaches and quantitative data on the functioning of transnational families remained limited, these analyses contribute to the filling in of an important gap.

Results confirm that transnational families keep their unity and continue to maintain relations of mutual support (Bryceson and Vuorela, 2002; Litwak, 1960). All members of transnational families have a special role in terms support transfers and they try to maintain a certain family cohesion, even when separated by long distances and the national borders (Baldassar et al., 2007). 
Data shows a significant number of extended families whose younger members are internal or international migrants. The results became more interesting when migration status is compared between siblings. It cannot be neglected the fact that numerous extended families have members of the same generational line with different migration statuses (non-migrants, internal migrants and external migrants). This may be a result of negotiated arrangements between family members (Baldassar, 2007a). When the situation requires, someone will keep living with parents in order to provide the instrumental help required, while others will leave the parental household in search for a better job which could allow contributing with money for the parents left at home. Still, the percentage of all migrant adult children is not to be forgotten. Further analysis considering the health status of parents and their care needs might assure a plus for our interpretation.

As expected, geographic distance is closely related to the type of help provided. Practical support is more common in cases of spatial proximity between households. The main role of international migrant adult-children is the provision of material help (remittances), but other form of support cannot be neglected either. In what concerns internal migrant children, they are far more often providers of practical help than material help (or both).

Parents are not only beneficiaries of support, they are also providers. For both cases of migration, parents were ready to help their adult children. When adult children work abroad, the support provided by parents does not consists of financial aid, but in practical help via frequent contact and shorter periods of separation. In the case of adult children who live in country, the results overlap with previous studies for the case of Romania. Parents receive from their adult children instrumental or practical support, while they offer material support and help with caring for their grandchildren (Mureșan, 2012a: 231; Hărăguș, 2014; Földes, 2015; Mureșan and Hărăguș, 2015).

Even if the geographical distance is not an obstacle for the existence of intergenerational transfers, the situation changes once the time variable is added. Previous studies about transnationality show that spending more time abroad has a "cooling" effect on the intensity of kin relations (Baldassar, 2007a). The same can be observed easily in all analyses presented in this paper. As mentioned in previous section, this is caused by shifting the investment of social, economic and cultural capital from the country of origin to the country of destination. When departure lasted 20 years or more, no transfers at all occurred. However, the data does not allow us to discern whether international migrants used to be internal migrants before. So, leaving the parental home could not coincide with living the country. Moreover, persons who emigrated 20 years ago or before belong to another migration regime, completely different from that after 2000 , and this fact makes interpretations difficult. 
Other limitation of the present paper is given by the fact that analyses point out only the kin relation of parents with the oldest adult child. Also, because multiple correspondence models do not imply causality, the results could not provide clear information about the factors which contribute directly to changes in help behaviour of the extended family members. Beyond these limitations, this paper managed to reach its objectives of presenting a more complex and up-to-date picture of the growing category of multigenerational transnational families originating in Romania.

\section{REFERENCES}

Anghel, R. G. (2008). Changing Statuses: Freedom of Movement, Locality and Transnationality of Irregular Romanian Migrants in Milan. Journal of Ethnic and Migration Studies, 34(5): 787-802.

Baldassar, L. (2007a). Transnational families and aged care: The mobility of care and the migracy of ageing. Journal of Ethnic and Migration Studies, 33(2): 275-297.

Baldassar, L. (2007b). Transnational families and the provision of moral and emotional support: the relationship between truth and distance. Identities: Global Studies in Culture and Power, 14(4): 385-409.

Baldassar, L., Baldock, C. V., Wilding, R. (2007). Families caring across borders: migration, ageing, and transnational caregiving. London: Palgrave Macmillan.

Ban, C. (2012). Economic Transnationalism and its Ambiguities: The case of Romanian Migration to Italy. International Migration, 50(6): 129-149.

Basch, L., Glick Schiller, N., Szanton Blanc, C. (2005). Nations unbound: transnational projects, postcolonial predicaments, and deterritorialized nation-states. London: Routledge.

Bawin-Legross, B., and Stassen, J. F. (2002). Intergenerational solidarity: Between the family and the state. Current Sociology, 50(2): 243-262.

Bengtson, V. L., and Schrader, S. S. (1982). Parent-Child Relations. In D. J. Mangen, and W. A. Peterson (eds.): Research Instruments in Social Gerontology, Vol. 2. Minneapolis: University of Minnesota Press, pp. 115-128.

Bengtson, V. L., Rosenthal, C. J., Burton, L. M. (1990). Families and ageing: Diversity and heterogeneity. In R. H. Binstock, and L. K. George (eds.): Handbook of ageing and the social sciences. New York: Academic Press, pp. 263-287.

Bengtson, V. L., Roberts, R.E.L. (1991). Intergenerational solidarity in aging families: An example of formal theory construction. Journal of Marriage and Family, 53(4):856870.

Bianchi, S. M., Hotz, V. J., McGarry, K. M., Seltzer, J. A. (2006). Intergenerational ties: Alternative theories, empirical findings and trends, and remaining challenges. Paper prepared for the 2006 Penn State Symposium on Family Issues, "Caring and Exchange within and across Generations" October $4^{\text {th }}$ and 5th, State College, PA., pp.1-53. 
Bryceson, D., and Vuorela, U. (2002). The transnational family: new European frontiers and global networks. New York: Berg - Oxford International Publishers.

Culic, I. (2004). Metode avansate în cercetarea socială: analiza multivariată de interdependență [Advanced methods of statistical analysis: multivariate analysis of interdependence]. Iași: Polirom.

Centre for Urban and Regional Studies - CURS. (2011). The impact of migration on older parents left behind in Romania (IPIA survey).

Diminescu, D. (2009). Exercițiul dificil al liberei circulații: o introducere în istoria migrației recente a românilor [The difficult exercise of free movement: an introduction to the history of Romanians' recent migration]. In R. G. Anghel and I. Horvath (eds.): Sociologia migrației. Teorii și studii de caz românești [The sociology of migration. Theories and Romanian case studies]. Iași: Polirom, pp.45-62.

Földes, I. (2015). Intergenerational care giving transfers within kinship relations: Rural-urban comparison. Romanian Journal of Population Studies, IX(1): 104-128.

Haberkern, K., and Szydlik, M. (2010). State care provision, societal opinion and children's care of older parents in 11 European countries. Ageing \& Society, 30(2): 299-323.

Hărăguș, M. (2014). Intergenerational Solidarity in Co-Residential Living Arangements. Revista de Asistență Socială, XIII(4): 1-15.

Horvath, I. (2012). Migrația internațională a cetățenilor români dupa 1989 [The international migration of Romanian citizens after 1989]. In T. Rotariu, and V. Voineagu (eds.): Inerție și schimbare: dimensiuni sociale ale tranzitiei în România [Inertia and change: the social dimensions of transition in Romania]. Iași: Polirom, pp. 199-222.

Horvath, I., and Anghel, R. G. (2009). Introducere [Introduction]. In R. G. Anghel and I. Horvath (eds.): Sociologia migrației. Teorii și studii de caz românești [The sociology of migration. Theories and Romanian case studies]. Iași: Polirom, pp. 13-44.

Isengard, B. and Szydlik, M. (2012). Living Apart (or) Together? Coresidence of Elderly Parents and Their Adult Children in Europe. Research on Aging, 34(4): 449-474.

Leopold, T., and Raab, M. (2011). Short- Term Reciprocity in Late Parent - Child Relations. Journal of Marriage and Family, 73(1): 105-119.

Litwak, E. (1960). Geographic-mobility and extended family cohesion. American Sociological Review, 25(3): 385-394.

Litwak, E., and Kulis, S. (1987). Technology, proximity, and measures of kin support. Journal of Marriage and the Family, 49(3): 649-661.

Mangen, D. J., Bengtson, V. L., Landry, P. H. (1988). Measurement of Intergenerational Relations. Newbury Park, CA: Sage.

Mureșan, C. (2012a). Schimbările comportamentului familial din România: o abordare din perspectiva cursului vieții [Changes in the family behaviour in Romania: the life-course approach]. Cluj-Napoca: Presa Universitară Clujeană.

Mureșan, C. (2012b). Situația demografică [Demographic situation]. In C. Mureșan, M. Hărăguș, P. T. Hărăguș, A. Rebeleanu, T. Rotariu, C. Faludi (eds.): Situația Vârstnicilor din România [The situation of the elderly in Romania]. Cluj-Napoca: Presa Universitară Clujeană, pp. 11-27. 
Mureșan, C. (2012c). Schimbarea structurilor familiale și slăbirea solidarității familial [Changes in family structures and the weakening of solidarity within the family]. In C. Mureșan, M. Hărăguș, P. T. Hărăgus, A. Rebeleanu, T. Rotariu , C. Faludi (eds.): Situația vârstnicilor din România [The situation of the elderly in Romania]. ClujNapoca: Presa Universitară Clujeană, pp. 79-100.

Mureșan, C. and Hărăguș, P.T. (2015). Norms of filial obligation and actual support to parents in Central and Eastern Europe. Journal of Population Studies, IX(2): 49-81.

Nadolu, B., Nadolu, I. D., Asay, S. M. (2007). Family strenghts in Romania. Marriage \& Family Review, 41(3-4):419-446.

Pantea, M. C. (2011). Grandmothers as main caregivers in the context of parental migration. European Journal of Social Work, 15(1): 63-80.

Pantea, M. C. (2012). 'I have a child and a garden': young people's experiences of care giving in transnational families. Journal of Youth Studies, 15(2): 241-256.

Rossi, A. S., and Rossi, P. H. (1990). On human bonding: parent-child relations across the life curse. New York: Aldine de Gruyter.

Sandu, D., and Alexandru, M. (2009). Migrația și consecințele sale [Migration and its consequences]. In M. Preda (eds.): Riscuri și inechități sociale în România. Raportul Comisiei Prezidențiale pentru Analiza Riscurilor Sociale și Demografice [Social risks and inequities in Romania. The report of the Presidential Commission for the Analysis of Social and Demographic Risks]. Iași: Polirom, pp. 287-304.

Schmalzbauer, L. (2004). Searching for wages and mothering from afar: the case of Honduran transnational families. Journal of Marriage and the Family, 66(5): 13171331.

Toth, G. (2009). Remiterile de bani ale migranților români din regiunea Madrid și paternurile de utilizare a acestora [Remittances sent home by Romanian migrants in the Madrid region and patterns of their usage]. In D. Sandu (eds.): Comunități românești în Spania [Romanian communities in Spain]. București: Fundația Soros România, pp. 129-141.

Toth, G., nad Toth, A. (2006). Relații de familie [Family relations]. In D. Sandu (eds.): Locuirea temporară în străinătate. Migrația economică a românilor: 1990-2006 [Temporary residence abroad. The economic migration of Romanians: 19902006]. București: Fundația pentru o Societate Deschisă, pp. 61-67.

Wilding, R. (2006). "Virtual" intimacies? Transnational communications across transnational borders. Global Networks, 6(2): 125-142.

World Bank (2016). Migration and Remittances Factbook. Washington: The World Bank.

Zimmer, Z., Rada, C., Stoica, C. A. (2014). Migration, Location and Provision of Support to Older Parents: The Case of Romania. Journal of Population Ageing, 7: 161-184. 


\section{APPENDIX A}

Table A1.

Summary of multiple correspondence model for intergenerational transfers with international migrant adult-child and time spent abroad

\begin{tabular}{|l|l|l|l|}
\hline \multirow{2}{*}{ Dimension } & \multirow{2}{*}{ Cronbach's Alpha } & \multicolumn{2}{|c|}{ Variance Accounted For } \\
\cline { 3 - 4 } & & Total (Eigenvalue) & Inertia \\
\hline 1 & .913 & 3.168 & .792 \\
\hline 2 & .649 & 1.949 & .487 \\
\hline Total & & 5.118 & 1.279 \\
\hline Mean & $.812^{\text {a }}$ & 2.559 & .640 \\
\hline
\end{tabular}

Data source: IPIA, 2011. Author's calculations.

Table A2.

Summary of multiple correspondence model for intergenerational transfers with international migrant adult-child and frequency of contact by telephone and the Internet

\begin{tabular}{|l|l|l|l|}
\hline \multirow{2}{*}{ Dimension } & \multirow{2}{*}{ Cronbach's Alpha } & \multicolumn{2}{|c|}{ Variance Accounted For } \\
\cline { 3 - 4 } & & Total (Eigenvalue) & Inertia \\
\hline 1 & .914 & 3.176 & .794 \\
\hline 2 & .625 & 1.882 & .471 \\
\hline Total & & 5.058 & 1.265 \\
\hline Mean & $.806^{\mathrm{a}}$ & 2.529 & .632 \\
\hline
\end{tabular}

Data source: IPIA, 2011. Author's calculations. 


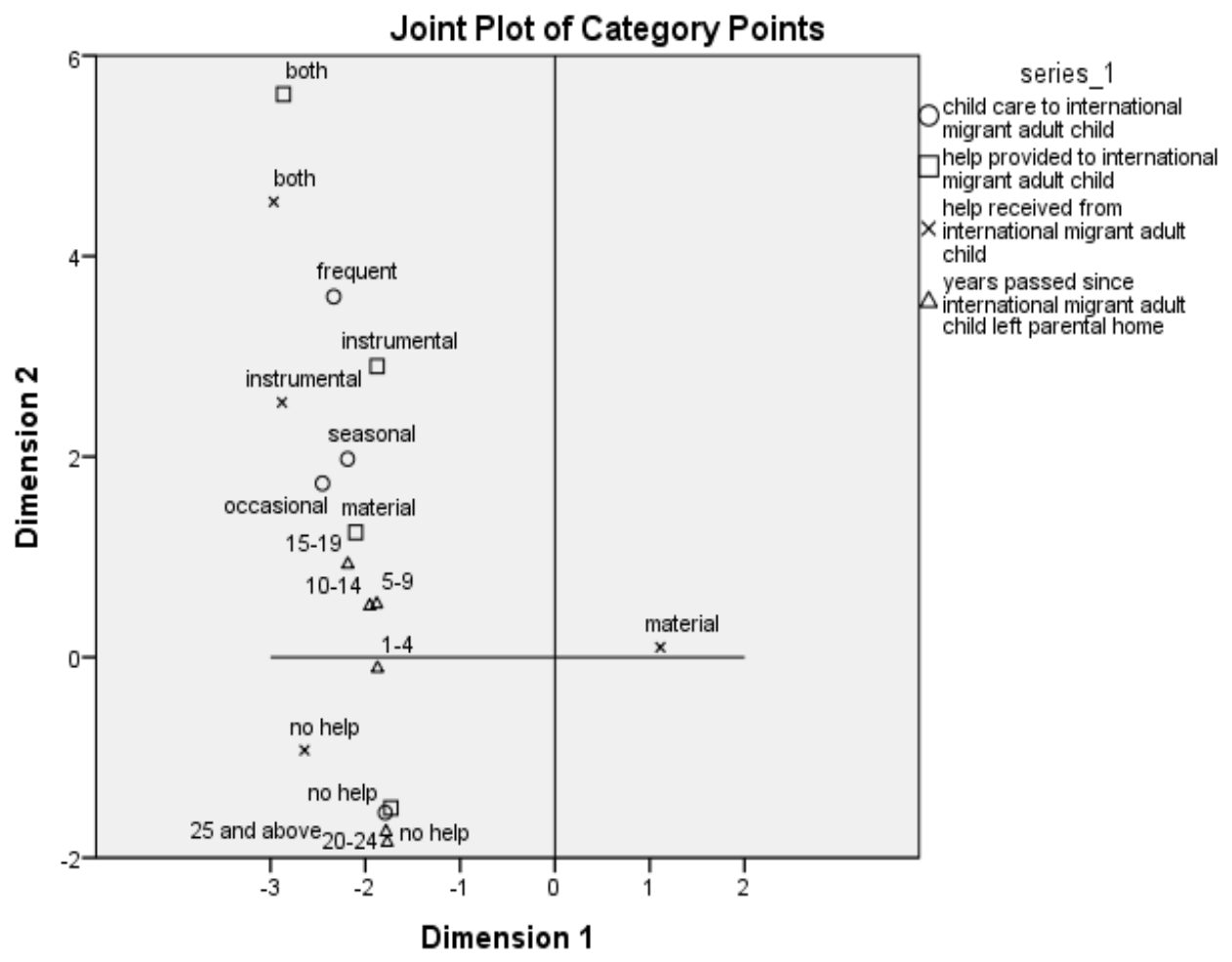

Variable Principal Normalization.

Figure A1. Plot of category points for multiple correspondence model for intergenerational transfers with international migrant adult-child and time spent abroad

Data source: IPIA, 2011.Author's calculations. 


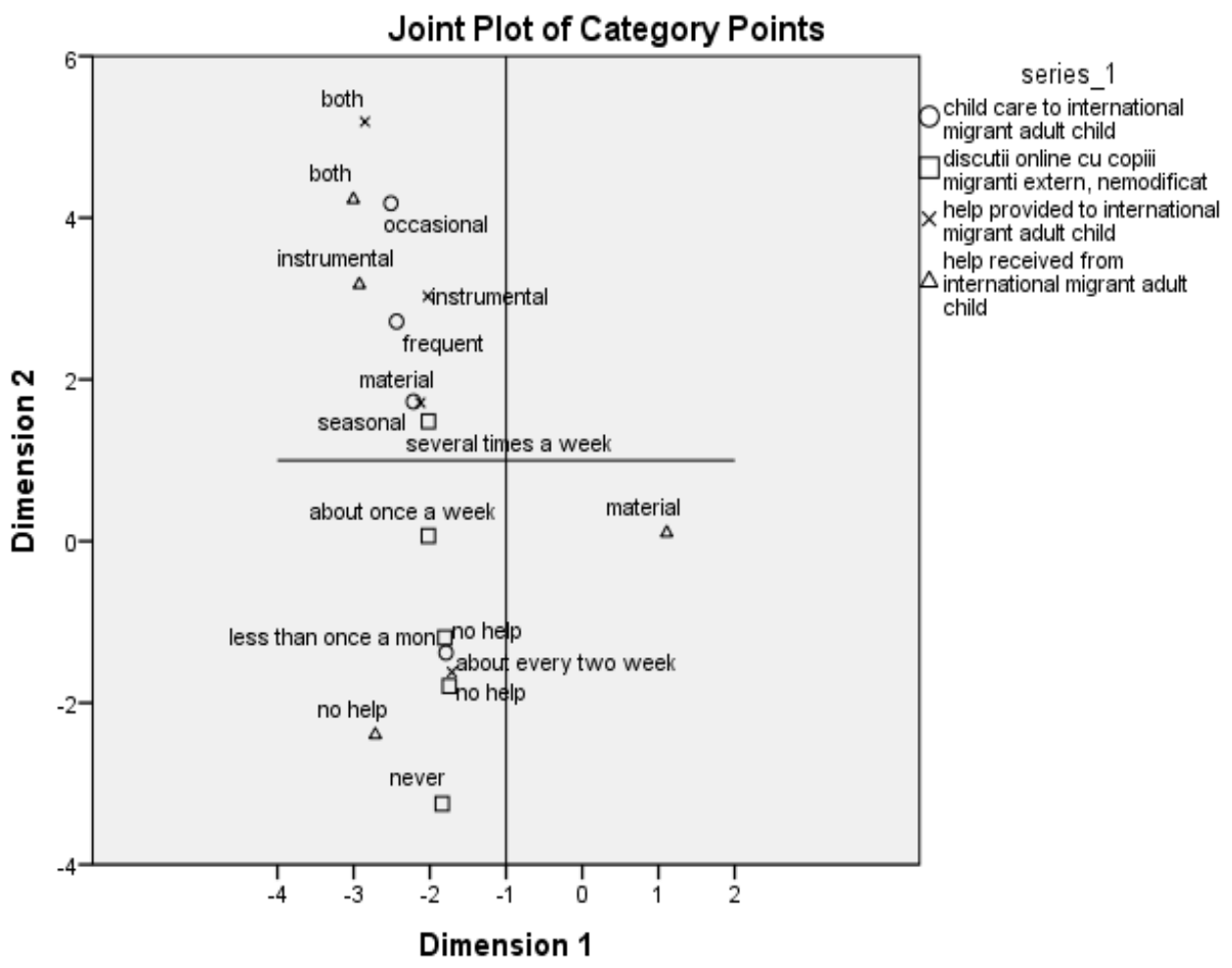

Variable Principal Normalization.

Figure A2. Plot of category points for multiple correspondence model for intergenerational transfers with international migrant adult-child and frequency of contact by telephone and Internet

Data source: IPIA, 2011. Author's calculations. 


\section{APPENDIX B}

Table B1.

Summary of multiple correspondence model for intergenerational transfers with internal migrant adult-child and time passed since living in other locality

\begin{tabular}{|l|l|l|l|}
\hline \multirow{2}{*}{ Dimension } & \multirow{2}{*}{ Cronbach's Alpha } & \multicolumn{2}{|c|}{ Variance Accounted For } \\
\cline { 3 - 4 } & & Total (Eigenvalue) & Inertia \\
\hline 1 & .604 & 1.828 & .457 \\
\hline 2 & .456 & 1.519 & .380 \\
\hline Total & & 3.347 & .837 \\
\hline Mean & $.537 \mathrm{a}$ & 1.674 & .418 \\
\hline
\end{tabular}

Data source: IPIA, 2011. Author's calculations.

Table B2.

Summary of multiple correspondence model for intergenerational transfers with internal migrant adult-child and frequency of contact by telephone and the Internet

\begin{tabular}{|l|l|l|l|}
\hline \multirow{2}{*}{ Dimension } & \multirow{2}{*}{ Cronbach's Alpha } & \multicolumn{2}{|l|}{ Variance Accounted For } \\
\cline { 3 - 4 } & & Total (Eigenvalue) & Inertia \\
\hline 1 & .563 & 1.730 & .433 \\
\hline 2 & .421 & 1.462 & .365 \\
\hline Total & & 3.192 & .798 \\
\hline Mean & $.498^{\mathrm{a}}$ & 1.596 & .399 \\
\hline
\end{tabular}

Data source: IPIA, 2011. Author's calculations. 


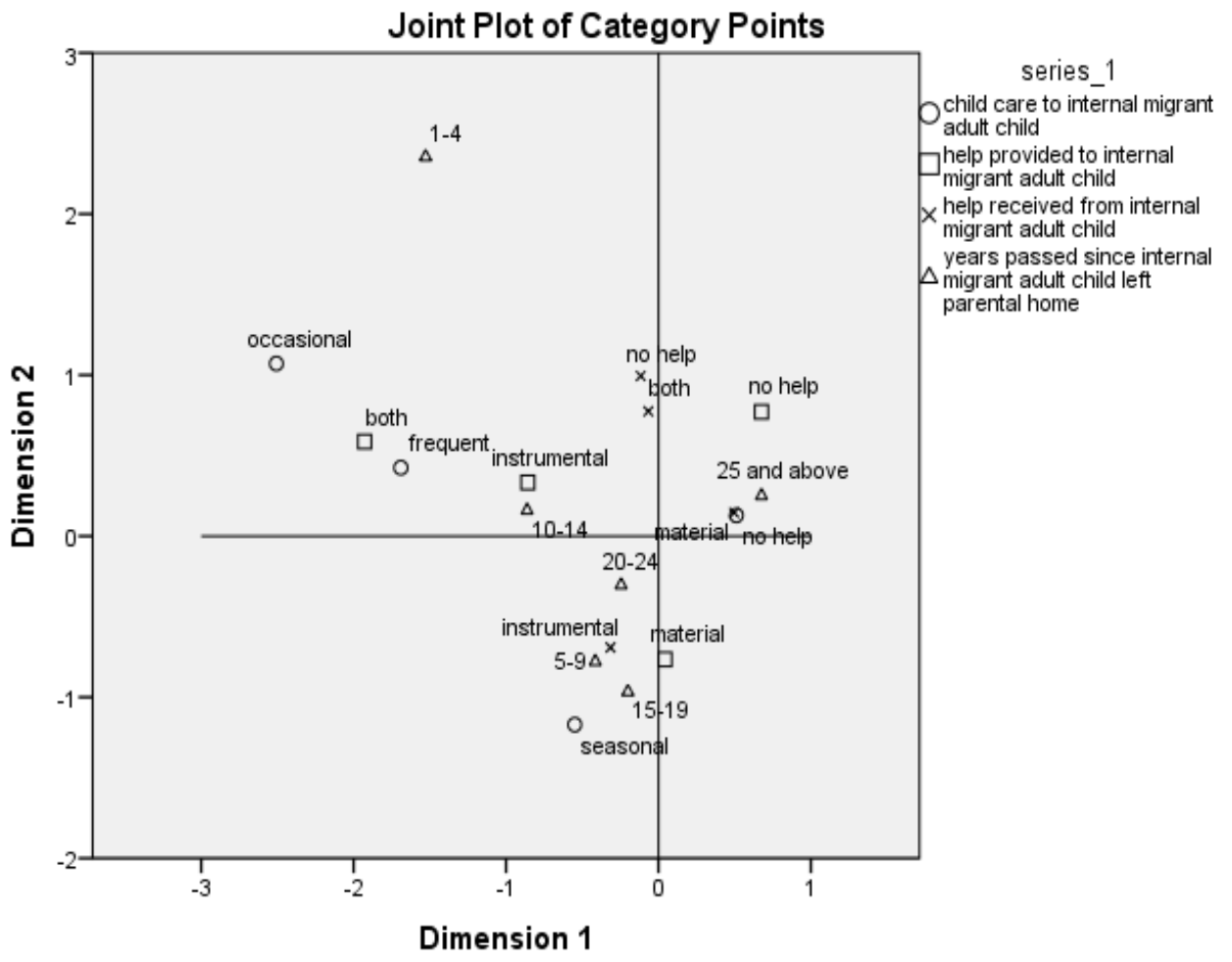

Variable Principal Normalization.

Figure B1. Plot of category points for multiple correspondence model for intergenerational transfers with internal migrant adult-child and time passed since living in other locality

Data source: IPIA; author's calculations. 


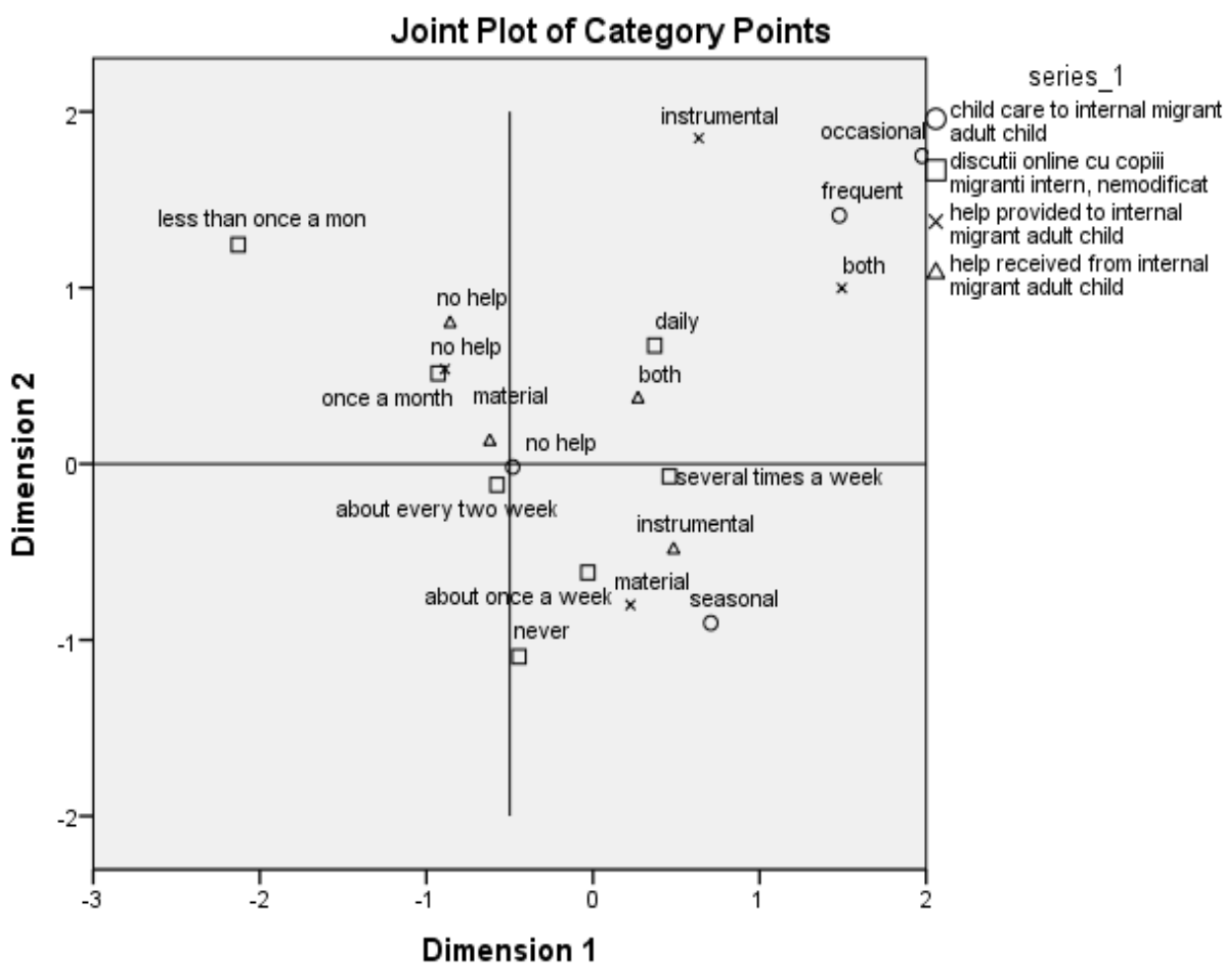

Variable Principal Normalization.

Figure B2. Plot of category points for multiple correspondence model for intergenerational transfers with internal migrant adult-child and frequency of contact by telephone and the Internet

Data source: IPIA, 2011. Author's calculations. 
